\title{
GAMBARAN HARGA DIRI REMAJA PUTRI YANG MELAKUKAN SEKS PRANIKAH
}

\author{
Karen Christy $^{1}$, Shanty Sudarji ${ }^{2}$ \\ Program Studi Psikologi Universitas Bunda Mulia \\ ${ }^{1}$ Karenkristy95@gmail.com, ${ }^{2}$ Gbu120711@gmail.com
}

\begin{abstract}
Puberty is experienced in adolescence that causes physical and sexual maturity. Sexual hormones that have begun to work encourage adolescents to engage in sexual behavior. Women are referred to as the most disadvantaged if they have premarital sex without long-term commitment. And losing your virginity will affect your self-esteem such as feeling insecure, embarrassed, guilty, sinful, dirty, scared, worried, fear not accepted and humiliation and others will arise after having premarital sex. The purpose of this study is to get an overview and know how the self-esteem of teenage girls who have premarital sex. The research method used in this study is qualitative research with phenomenological approach and using interview and observation method to obtain research data. Respondents in this study were five teenage girls who had premarital sex. The results in this study showed that only one respondent fulfilled all aspects of self-esteem. Then, three respondents fulfilled the aspect of feeling of worth. Two respondents fulfilled the aspect of feeling of competence, and two respondents fulfilled the feelings of belonging. The existence of family factors that also affect the respondents to perform premarital sex behavior as well as the existence of environmental factors, personality factors and hormonal factors. Premarital sex performed by these five respondents can be a picture that premarital sex in teenagers is a natural thing to do with a partner as a form of peak of love by teenagers though not married. So that adolescents are expected to study sex education by attending seminars to find out the impacts if premarital sex.
\end{abstract}

Keywords: Self-esteem, Self-esteem in teenage girls, teenage girls, premarital sex

\begin{abstract}
ABSTRAK
Pubertas dialami pada masa remaja yang menyebabkan kematangan secara fisik maupun seksual. Hormon seksual yang sudah mulai berfungsi mendorong remaja untuk melakukan perilaku seksual. Wanita disebut sebagai pihak yang paling dirugikan jika melakukan seks pranikah tanpa komitmen jangka panjang. Dan kehilangan keperawanan akan mempengaruhi harga diri seperti merasa tidak percaya diri, malu, rasa bersalah, berdosa, kotor, takut, khawatir, rasa takut tidak diterima serta penghinaan dan lainnya akan timbul setelah melakukan hubungan seks pranikah. Tujuan penelitian ini adalah untuk mendapat gambaran dan mengetahui bagaimana harga diri remaja putri yang melakukan seks pranikah. Metode penelitian yang digunakan dalam penelitian ini adalah metode penelitian kualitatif dengan pendekatan fenomenologis dan menggunakan metode wawancara dan observasi untuk memperoleh data penelitian. Penelitian dilakukan pada lima remaja putri yang melakukan seks pranikah. Hasil penelitian menunjukkan bahwa hanya satu responden yang memenuhi seluruh aspek harga diri. Lalu, tiga responden memenuhi aspek perasaan berharga. Dua responden memenuhi aspek perasaan mampu, dan dua responden memenuhi aspek perasaan diterima. Adanya faktor keluarga yang juga mempengaruhi responden untuk melakukan perilaku seks pranikah serta adanya faktor lingkungan, faktor kepribadian dan faktor hormonal. Seks pranikah yang dilakukan oleh kelima responden ini dapat dijadikan gambaran bahwa seks pranikah dimata remaja merupakan hal yang wajar untuk dilakukan dengan kekasih sebagai wujud puncak cinta oleh remaja meskipun belum menikah. Sehingga remaja diharapkan untuk mempelajari pendidikan seks dengan mengikuti seminar untuk mengetahui dampak-dampak jika melakukan seks pranikah.
\end{abstract}

Kata Kunci: Harga Diri, Harga Diri Remaja Putri, Remaja Putri, Seks Pranikah 


\section{PENDAHULUAN}

Remaja adalah aset sumber daya manusia yang merupakan tulang punggung penerus generasi di masa mendatang. Pada dasarnya, remaja adalah masa transisi dari masa kanak-kanak ke masa dewasa. Berdasarkan hasil proyeksi penduduk Indonesia menurut kelompok umur dan jenis kelamin tahun 2010-2035, terlihat pada tahun 2017 jumlah remaja usia (15-24 tahun) berjumlah 43.916.000 (Proyeksi Penduduk Indonesia 2010-2035, 2013). Jumlah remaja yang sangat besar tersebut adalah potensi yang memerlukan pengelolaan secara terencana, sistematis dan terstruktur agar dapat dimanfaatkan menjadi modal pembangunan bangsa ke depan (BKKBN, 2016)

Terminologi remaja sendiri telah diterjemahkan menjadi beberapa arti. Secara lengkap, definisi remaja harus mempertimbangkan perubahan biologis, psikologi dan sosial. Akan tetapi perubahan biologis terjadi lebih cepat dibandingkan perubahan psikologi dan sosial. Hal tersebut dapat membuat remaja merasa bingung dengan perubahan yang terjadi. Hormon seksual pun sudah mulai berfungsi pada masa remaja. Hal tersebut mendorong remaja untuk melakukan berbagai jenis perilaku seksual (Mahmudah, Yaunin, \& Lestari, 2016).

Pada umumnya remaja memiliki rasa ingin tahu yang tinggi (high curiousity). Remaja cenderung ingin berpetualang menjelajah segala sesuatu dan mencoba segala sesuatu yang belum pernah dialaminya. Selain didorong juga oleh keinginan menjadi seperti orang dewasa menyebabkan remaja ingin mencoba melakukan apa yang sering dilakukan orang dewasa termasuk yang berkaitan dengan masalah seksualitas (Azwar dalam Azinar, 2013). Hubungan seksual ini umumnya terjadi diantara mereka yang telah meningkat remaja menuju dewasa. Hal ini sangat mungkin terjadi mengingat pada saat seseorang memasuki masa remaja mulai timbul dorongan-dorongan seksual di dalam dirinya. Apalagi pada masa ini minat mereka dalam membina hubungannya terfokus pada lawan jenis (Ervina, 2015).
Menurut Direktur Bina Ketahanan Remaja Badan Koordinasi Keluarga Berencana Nasional (BKKBN), ada tiga masalah besar yang dihadapi oleh para remaja saat ini, selain narkoba dan HIV/AIDS, persoalan utama remaja Indonesia saat ini adalah seks bebas (BKKBN, 2015). Seks pranikah (seks bebas) atau dalam bahasa populernya disebut extramarital intercourse merupakan bentuk pembebasan seks yang dipandang tidak wajar, baik oleh agama maupun oleh negara. Menurut hasil survei dari Komnas Perlindungan Anak, bahwa saat ini sekitar $62,7 \%$ remaja SMP Indonesia sudah tidak perawan lagi, dan hampir $21,2 \%$ remaja SMU sudah pernah melakukan aborsi. Penelitian yang sama juga dilakukan oleh Dr. Boyke terhadap pelajar dan mahasiswa, hasilnya sekitar 18-20\% remaja di Indonesia pernah melakukan hubungan seks bebas (Tipani dalam Dona, 2016).

Dalam pandangan budaya Timur, melakukan hubungan seks sebelum menikah adalah perilaku yang dilarang. Selain bertentangan dengan norma agama dan budaya, hal tersebut ternyata juga memiliki konsekuensi pada kehidupan wanita setelahnya. Dalam hal ini, wanita disebut sebagai pihak yang paling dirugikan dan kebanyakan melakukan seks tanpa komitmen jangka panjang (Deviyana, 2014). Budaya Indonesia yang menggunakan adat Timur ini masih beranggapan bahwa seks bebas dan aktivitas seksual pranikah dianggap sangat tabu, dan virginitas atau keperawanan dianggap sangat penting sebagai lambang kesucian bagi seorang perempuan serta betapa berharganya keperawanan mereka untuk kehidupan mereka nantinya (Tipani dalam Dona, 2016).

Hilangnya keperawanan bisa berakibat depresi atau kecemasan yang mendalam pada wanita yang bersangkutan (Hadi dalam Ervina, 2015). Perasaan-perasaan negatif seperti hilangnya keperawanan, rasa malu, rasa bersalah, rasa berdosa, kotor, takut, khawatir dan lainnya akan timbul setelah mereka melakukan hubungan seks pranikah. Keperawanan ternyata berkaitan erat dengan harga diri; perempuan yang telah melakukan hubungan seks pranikah akan menimbulkan perilaku yang berdampak pada harga dirinya 
(Sari, 2009). Steinberg (dalam Sari, 2009) juga mengatakan bahwa harga diri merupakan konstruk yang penting dalam kehidupan sehari-hari juga berperan serta dalam menentukan tingkah laku seseorang. Menurut Santrock (Mulyana dan Purnamasari, 2010) remaja masih dalam situasi peralihan dan krisis dalam menemukan identitas dirinya sehingga perasaan berharga dan bernilai sangatlah dibutuhkan oleh remaja.

\section{Self esteem}

Self esteem merupakan suatu penilaian pribadi yang dilakukan individu mengenai perasaan berharga atau berarti dalam sikapsikap individu terhadap dirinya (Coopersmith dalam Muslimah \& Wahdah, 2013). Terdapat beberapa aspek harga diri (self esteem) menurut Coopersmith (dalam Machini, Nafikadini \& Gani, 2015) yaitu perasaan berharga, perasaan mampu dan perasaan diterima. Perasaan berharga (feeling of worth), perasaan yang dimiliki oleh individu saat merasa dirinya berharga karena dihargai oleh orang lain. Individu yang merasa dirinya berharga, akan dapat mengekspresikan dirinya dengan baik, dapat menerima kritik dan dapat mengontrol perilaku. Perasaan mampu (feeling of competence), Perasaan yang dimiliki pada saat individu merasa mampu untuk mencapai suatu hasil yang diharapkan. Individu yang memiliki harga diri positif menyukai tugas baru yang menantang, aktif dan tidak cepat bingung jika segala sesuatu berjalan tidak sesuai dengan rencana. Perasaan mampu dan kompeten ketika melaksanakan tugas, secara bertahap dapat meningkatkan harga diri remaja. Perasaan diterima (feeling of belonging), Perasaan yang dimiliki individu ketika individu diterima sebagai dirinya sendiri oleh suatu kelompok, yaitu diperlakukan sebagai bagian dari kelompok, maka individu terse but akan merasa dirinya diterima dan dihargai oleh kelompok tersebut.

\section{Remaja}

Remaja (adolescence) diartikan sebagai masa perkembangan transisi antara masa anak dan masa dewasa yang mencakup perubahan biologis, kognitif, dan sosialemosional (Santrock, 2010).

\section{Seks Pranikah}

Perilaku seks pranikah adalah perilaku-perilaku yang mengarah pada keintiman heteroseksual yang dilakukan oleh sepasang anak manusia sebelum adanya ikatan resmi (pernikahan) (Crooks dalam Nuandri \& Widayat, 2014). Seks pranikah adalah kontak seksual yang dilakukan remaja dengan lawan jenis atau teman sesama jenis tanpa ikatan pernikahan yang sah. Perilaku hubungan seksual pranikah dapat menyebabkan berbagai masalah bagi kesehatan, sosial dan ekonomi bagi remaja itu sendiri maupun keluarganya (BKKBN, 2016).

\section{METODE PENELITIAN}

Sampel yang digunakan dalam penelitian ini berjumlah 5 orang remaja putri dengan rentang usia 15-24 tahun dan sudah melakukan seks pranikah.

Teknik sampling yang digunakan adalah purposive sampling. $\mathrm{Hal}$ ini dikarenakan kasusnya yang kaya akan informasi namun sifatnya lebih subjektif karena menggali pengalaman yang berbedabeda pada tiap subjek dan pemilihan subjek berdasarkan opini peneliti bahwa subjek memenuhi kriteria, memiliki informasi dan juga bersedia untuk berbagi pengalaman dengan peneliti (Kumar, 2010).

Variabel yang digunakan dalam penelitian ini adalah harga diri. Metode penelitian yang digunakan dalam penelitian ini adalah metode penelitian kualitatif. jenis penelitian kualitatif yang digunakan adalah fenomenologis, yaitu penelitian yang didasarkan pada fenomena dan fenomena tersebut dilihat dan dimaknai secara subjektif (Willig, 2008).

Metode pengumpulan data yang digunakan dalam penelitian ini, antara lain observasi yang bertujuan untuk memperkaya data-data yang di dapat dari hasil wawancara, di mana observasi adalah pengamatan dan pencatatan secara sistematik terhadap gejala yang tampak dalam penelitian, dan juga melakukan wawancara mendalam (depth interview) pada autoanamnesa dan alloanamnesa yang bertujuan untuk menggali dan mengeksplorasi lebih dalam fenomena yang ingin diteliti. 
Teknik analisis data menggunakan teknik content analysis secara deduktif yaitu dari umum ke khusus (teori-fenomena) dengan mengkategorikan data-data berdasarkan dimensi agar tersusun rapi dan sistematis, melakukan coding terhadap verbatim hasil wawancara, dan peneliti juga melakukan interpretasi terhadap data-data dari responden kemudian mengaitkan dengan teori yang berhubungan dengan topik penelitian sehingga tujuan penelitian dapat tercapai. Lalu digunakan content analysis menggunakan metode deduktif, yaitu menggunakan dasar teori yang kuat sehingga dapat di cocokan dengan hasil penelitian.

\section{HASIL DAN PEMBAHASAN}

Berdasarkan hasil penelitian yang telah dilakukan, dapat disimpulkan bahwa alasan kelima subjek melakukan seks karena adanya pengaruh faktor eksternal menurut (Sudarsono, dalam Ervina, 2015) yaitu faktor keluarga karena orangtua subjek M, C, dan A telah bercerai. Kemudian $\mathrm{G}$ yang tidak memiliki hubungan yang dekat dengan keluarga dan $\mathrm{N}$ juga cenderung diberikan kebebasan oleh orangtuanya seperti merokok, pulang larut malam dan orangtuanya juga mengetahui bila $\mathrm{N}$ pergi ke klub malam.

Selain faktor keluarga, faktor eksternal lain yang mempengaruhi perilaku seks pranikah yaitu faktor modernisasi dan globalisasi kebudayaan yang menyebabkan permisifitas seks yang semakin tampak dalam kebudayaan masyarakat sebagai akibat dari adanya pergeseran nilai (Ervina, 2015). Kemudian faktor lingkungan dimana individu merupakan makhluk psikis dan sosial budaya yang pola perilakunya dipengaruhi oleh lingkungan dan interpretasinya terhadap lingkungan sekitarnya termasuk perilaku seksualnya (Kartono dalam Ervina, 2015).

Kelima subjek juga dipengaruhi oleh faktor internal yang mempengaruhi perilaku seks bebas di kalangan remaja menurut (Kartono, dalam Ervina, 2015) yaitu kepribadian karena mereka yang juga memiliki dorongan untuk melakukan seks pranikah. Kelima subjek mau melakukan seks pranikah karena mereka merasa sayang kepada pasangannya tersebut sehingga mereka melakukan seks pranikah sebagai bentuk perwujudan cinta. $\mathrm{C}$ yang merasa dirinya memiliki dorongan seksual yang tinggi karena hormon seksual dalam dirinya.
Menurut Coopersmith (dalam Machini, et al., 2015) harga diri memiliki aspek perasaan berharga yaitu merasa dihargai oleh orang lain, dapat mengekspresikan dirinya dengan baik, manu menerima kritik dan dapat mengontrol perilaku. Subjek M, C dan A memenuhi seluruh bagian pada aspek perasaan berharga. Pada bagian merasa dirinya dihargai oleh orang lain, subjek M, C, A dan N merasa dihargai. Seperti subjek M yang kini sudah memiliki anak akibat perilaku seks pranikahnya tersebut awalnya merasa malu, tidak percaya diri dan takut terhadap dampak sosial seperti mendapat penolakan dari keluarga dan juga teman-teman karena kehamilan yang tidak diinginkan tersebut. Akan tetapi ternyata orang-orang di lingkungannya tersebut dapat menerima serta menghargainya sehingga $M$ merasa dirinya berharga. $\mathrm{C}$ juga awalnya merasa takut ditolak oleh kelompoknya tersebut yang ratarata belum melakukan seks pranikah, akan tetapi setelah terbuka, teman-temannya tetap menghargai keputusannya untuk melakukan seks pranikah bahkan merasa hubungan $\mathrm{C}$ dengan teman-temannya menjadi lebih akrab. Teman-teman $\mathrm{A}$ dan $\mathrm{N}$ juga merasa seks pranikah itu wajar dilakukan dan orang-orang disekitarnya dapat menghargai dirinya yang sudah tidak perawan. Sedangkan $G$ merasa perilaku seks pranikahnya dapat dihargai karena dirinya juga tidak di judge atau ditolak karena dirinya sudah tidak perawan, akan tetapi subjek tidak dihargai karena sifat $G$ yang menurut orang menjengkelkan sehingga perlahan $\mathrm{G}$ merasa orang-orang di sekitarnya menjauhi dirinya.

Dalam menanggapi suatu kritik, subjek $\mathrm{M}, \mathrm{C}, \mathrm{A}$ dan $\mathrm{N}$ merasa dapat menerima kritik apapun yang diberikan kepada mereka karena pada dasarnya seks pranikah memang tidak boleh dilakukan baik menurut agama maupun moral sehingga wajar saja jika ada yang memberi kritik kepada mereka. Berbeda dengan $\mathrm{G}$ yang tidak bisa menerima kritik. $\mathrm{G}$ akan sangat sensitif jika diberikan kritik dan 
mudah tersinggung. $\mathrm{G}$ tidak mau mendengarkan karena merasa dirinya memiliki sifat yang keras dan sulit menerima kritik.

Subjek M, C, A dan N dapat mengekspresikan dirinya seperti $\mathrm{M}$ yang telah menerima dirinya sendiri dan merasa tidak malu menunjukkan dirinya yang sudah mempunyai anak tanpa suami. $\mathrm{C}$ juga tidak malu lagi untuk menunjukkan dirinya yang sudah melakukan seks pranikah bahkan ia merasa lega setelah terbuka dengan orangorang disekitarnya bahwa ia sudah tidak perawan. A dan $\mathrm{N}$ juga dapat menunjukkan diri mereka apa adanya yang perokok, suka dunia malam bahkan mereka menunjukkan hal tersebut di sosial media bernama Instagram. Berbeda dengan $G$ yang tidak bisa mengekspresikan dirinya seperti kritik yang ia terima terkait dengan sifatnya yang buruk. Karena mendapat kritik tersebut, $G$ mencoba untuk lebih menjaga perkataannya. Akan tetapi $\mathrm{G}$ merasa tidak nyaman karena tidak bisa menjadi dirinya sendiri sehingga membuat dirinya menjadi stres.

Dalam mengontrol perilaku, M merasa ia bisa mengontrol perilakunya seperti tidak mau mengulangi perilaku seks pranikah lagi karena takut akan terjadi hal-hal yang tidak menyenangkan seperti yang dialaminya saat ini yaitu hamil diluar nikah. $\mathrm{C}$ juga merasa dirinya dapat mengontrol perilaku seks pranikah. Meskipun C mengakui bahwa dirinya menyukai melakukan seks pranikah, akan tetapi ia tahu bahwa perilakunya tersebut salah karena $\mathrm{C}$ melakukan dengan berberapa pria manapun yang bukan kekasihnya. A juga bisa mengontrol perilakunya yang dahulu suka pergi ke klub malam hingga tidak pulang kerumah dan kini ia menuruti perintah Ayahnya untuk tidak melakukan seperti itu lagi. A juga sudah tidak mau melakukan seks pranikah dengan lakilaki random dan hanya mau melakukannya dengan kekasihnya saja. Berbeda dengan $\mathrm{N}$ dan $G$ yang tidak dapat mengontrol perilakunya. Meskipun $\mathrm{N}$ sudah dihukum oleh orangtuanya untuk tidak terlibat dengan kenakalan remaja, akan tetapi $\mathrm{N}$ tetap mengulanginya. $\mathrm{G}$ juga tidak bisa mengontrol perilaku karena $G$ merupakan orang yang emosional.
Menurut Coopersmith (dalam Machini, et al., 2015) harga diri juga memiliki aspek perasaan mampu yaitu dimana individu merasa mampu untuk mencapai suatu hasil yang diharapkan, menyukai tugas baru yang menantang, aktif dan tidak cepat bingung jika segala sesuatu berjalan tidak sesuai rencana. Yang memenuhi aspek kedua yaitu subjek $M$ dan C.

Berkaitan dengan kemampuan mencapai suatu hasil yang diharapkan, kelima subjek merasa diri mereka mampu untuk mencapainya. Dalam hal menyukai jika menghadapi suatu tugas baru dan menantang, subjek M, C dan G memenuhi hal tersebut karena menurut mereka tugas baru itu adalah sesuatu yang seru, menyenangkan, tidak membuat bosan dan bisa dijadikan sebagai pengalaman untuk belajar. Mereka menyukai suatu tantangan dalam hidup mereka dan merasa yakin dapat menghadapi tantangan tersebut. Akan tetapi A dan $\mathrm{N}$ tidak menyukai jika mendapat suatu tugas baru dan menantang, mereka lebih suka berada di zona nyaman karena merasa tidak berniat untuk mengeluarkan kemampuannya untuk menghadapi tugas baru tersebut.

Kemudian dalam aspek kedua yakni aktif dan tidak cepat bingung jika segala sesuatu berjalan tidak sesuai dengan rencana, $\mathrm{G}$ akan tidak bisa menerima dan cenderung akan sangat kecewa dan marah karena $G$ cenderung egois dan ingin agar segala sesuatu harus berjalan sesuai dengan keinginannya. A dan $\mathrm{N}$ juga merasa jika sesuatu berjalan tidak sesuai dengan rencana mereka akan cenderung biasa saja dan merasa tidak masalah jika rencananya tersebut gagal. Berbeda dengan $\mathrm{M}$ dan $\mathrm{C}$ yang akan sangat aktif dan berusaha mencari jalan keluar untuk mencapai rencana tersebut seperti membuat rencana lain.

Menurut Coopersmith (dalam Machini, et al., 2015) harga diri juga memiliki aspek perasaan diterima yaitu merasa diterima sebagai dirinya sendiri di kelompok, diperlakukan sebagai bagan dari kelompok, merasa diterima dan dihargai oleh kelompok. Subjek C dan A memenuhi seluruh bagian pada aspek perasaan diterima. Kelima subjek merasa meskipun mereka sudah melakukan seks pranikah dan beberapa 
dari orang-orang di sekitarnya mengetahui hal tersebut, orang-orang di sekitarnya masih menerima mereka apa adanya baik dari keluarga, teman-teman maupun kekasih. Seperti M yang meskipun sudah hamil diluar nikah, akan tetapi orangtua, teman-teman terus memberi dukungan dan semangat kepada $M$ untuk tetap merawat anaknya tersebut. Kekasihnya juga menerima $\mathbf{M}$ yang telah memiliki anak.

$\mathrm{C}$ juga merasa bahwa dirinya diterima oleh keluarganya tersebut akan tetapi dirinyalah yang mencoba untuk menghindar dari keluarganya karena merasa dirinya tidak nyaman bersama dengan keluarga tirinya tersebut. A juga diterima oleh keluarganya meskipun dirinya dianggap anak yang nakal dan sulit diatur oleh orangtuanya. Ibu A juga mengetahui bahwa ia sudah tidak perawan, akan tetapi Ibu A tetap menerima A apa adanya dan memberi nasehat untuk lebih berhati-hati jangan sampai hamil akibat dari melakukan seks pranikah. $\mathrm{N}$ juga diterima oleh keluarganya meskipun $\mathrm{N}$ sempat ketahuan menggunakan narkoba, akan tetapi keluarganya tetap menyayangi $\mathrm{N}$ dan menganggap $\mathrm{N}$ sebagai anggota keluarga yang penting dan bisa diandalkan. $G$ juga diterima oleh keluarga yang sudah mengetahui dirinya sudah tidak perawan, akan tetapi $\mathrm{G}$ yang juga menolak untuk dekat dengan keluarganya karena memang G jarang melakukan komunikasi dengan keluarganya, hanya Ibunya saja yang mau menerima subjek baik sifat maupun perilaku subjek. Akan tetapi $\mathrm{G}$ merasa dirinya tidak diterima karena sifatnya yang buruk menurut orangorang disekitarnya yang membuat dirinya merasa dijauhi oleh lingkungan.

Pada bagian diterima sebagai bagian dari kelompok, subjek $M$, A dan $G$ tidak memenuhi karena subjek $M$ yang merasa dirinya perlahan dijauhi oleh kelompoknya dan tidak pernah lagi diajak untuk berkumpul bersama dengan kelompoknya. Kemudian $\mathrm{N}$ yang memang merasa dirinya memang tidak memiliki kelompok pertemanan yang akrab karena $\mathrm{N}$ yang mengakui bahwa dirinya memang tidak mudah untuk menjalin hubungan dengan siapa saja, ia hanya memiliki 1 sahabat saja dan sehari-hari ia hanya menghabiskan waktu bersama dengan kekasihnya. Dan G juga merasa tidak diperlakukan sebagai bagian dari kelompoknya. G dulu memiliki hubungan yang akrab dengan 3 orang teman perempuannya saat SMA. Akan tetapi semenjak bulan Juli tahun 2016, G sudah tidak bertemu dengan teman-temannya dan sampai saat ini jika $\mathrm{G}$ memberi pesan melalui aplikasi chat LINE, G seperti di abaikan. G merasa dirinya dijauhi oleh teman-temannya dan dikeluarkan dari kelompoknya.

\section{SIMPULAN DAN SARAN}

\section{Simpulan}

Berdasarkan hasil penelitian yang telah dilakukan, dapat disimpulkan bahwa subjek M, C dan A memenuhi aspek pertama dalam harga diri yaitu perasaan berharga. Subjek N juga memenuhi seluruh bagian dalam aspek perasaan berharga kecuali pada bagian dapat mengontrol perilaku. Sedangkan subjek $\mathrm{G}$ tidak memenuhi seluruh bagian dalam aspek perasaan berharga.

Subjek $\mathrm{M}$ dan $\mathrm{C}$ memenuhi aspek kedua dalam harga diri yaitu aspek perasaan mampu. Subjek A hanya memenuhi aspek kedua pada bagian merasa mampu untuk mencapai suatu hasil yang diharapkan dan juga perasaan mampu dan kompeten ketika melaksanakan tugas. Subjek $\mathrm{N}$ tidak memenuhi aspek perasaan mampu kecuali pada bagian merasa mampu untuk mencapai suatu hasil yang diharapkan. Sedangkan subjek $G$ juga memenuhi seluruh bagian dalam aspek perasaan mampu kecuali bagian aktif dan tidak cepat bingung jika segala sesuatu berjalan tidak sesuai dengan rencana.

Dalam aspek ketiga yaitu perasaan diterima, subjek $\mathrm{C}$ dan $\mathrm{A}$ memenuhi segala bagian dalam aspek perasaan diterima. Subjek M dan N juga memenuhi aspek perasaan diterima kecuali bagian diperlakukan sebagai bagian dari kelompok. Sedangkan subjek $\mathrm{G}$ tidak memenuhi aspek perasaan diterima.

Selain itu ditemukan bahwa empat dari kelima subjek menyatakan bahwa melakukan seks pranikah merupakan hal yang wajar untuk dilakukan dengan pacar atau pasangan sendiri. Mereka menunjukkan adanya permisifitas dalam seks yang membuat mereka mau melakukan seks jika diajak oleh pasangan mereka karena alasan sayang atau 
perwujudan cinta kepada pasangannya tersebut. Ini dikarenakan adanya faktor eksternal yaitu modernisasi dan globalisasi kebudayaan. Selain itu terdapat faktor eksternal lain yang mempengaruhi kelima subjek yaitu faktor keluarga dan faktor lingkungan. Kelima subjek juga dipengaruhi oleh faktor internal yaitu kepribadian karena mereka yang juga memiliki dorongan untuk melakukan seks pranikah dan juga faktor hormonal.

\section{Saran}

Berdasarkan hasil yang diperoleh dari penelitian ini, peneliti dapat menyarankan beberapa hal yaitu sebagai berikut. Bagi remaja agar dapat lebih mempelajari pendidikan seks melalui seminar atau psikoedukasi dan memahami nilai-nilai agama dan moral sosial dalam budaya Indonesia. Kemudian bagi orangtua diharapkan orangtua tidak mentabukan pembicaraan mengenai seksualitas dengan anak remajanya, sehingga remaja dapat memperoleh informasi yang benar tentang seksualitas. Dan bila memiliki anak yang terlibat dalam perilaku seks pranikah, diharapkan dapat memberikan dukungan secara mental terhadap anak serta tetap menerima kondisi anak.

Bagi masyarakat, diharapkan masyarakat bisa menciptakan lingkungan yang dapat mengurangi bahkan mencegah perilaku seks pranikah dengan mengoptimalkan peran Lembaga Swadaya Masyarakat (LSM) di tengah masyarakat untuk membantu melancarkan pelaksanaan program-program pemerintah. Bagi pemerintah, diharapkan pemerintah dapat lebih memperbanyak program-program pemerintah yang berkaitan dengan kesehatan reproduksi remaja dan dapat memberikan edukasi tentang pencegahan seks pranikah pada remaja baik di kota maupun di pedesaan.

Kemudian peneliti selanjutnya diharapkan untuk mengkaji masalah ini dengan jangkauan yang lebih luas dengan melibatkan variabel-variabel lain yang juga bisa menjadi faktor yang mempengaruhi kecenderungan remaja untuk melakukan hubungan seks pranikah.

\section{DAFTAR PUSTAKA}

Azinar, M. (2013). Perilaku Seksual Pranikah Berisiko Terhadap Kehamilan Tidak Diinginkan. Jurnal Kesehatan Masyarakat. Vol. 8 (2), 153-160.

Ervina, A. (2013). Harga Diri Remaja Putri dan Hubungan Seks Pranikah. Jurnal Obstretika Scientia. Vol. 1 (1).

Dona, L. (2016). The Relationship of SelfEsteem and Social Intelligence with The Perception of Virginity "SMK Negeri 1 Samarinda". Psikoborneo. Vol. 4 (3), 470-482.

Ismail, et al. (2016). Membangun Karakter Remaja. Jakarta: Badan Kependudukan dan Keluarga Berencana Nasional.

Kumar, R. (2010) Research Methodology: A Step-By-Step Guide for Beginners. 3rd ed. London: SAGE Publications.

Machini, F. N., Nafikadini, I., \& Gani, H. A. (2015) Self Esteem Pada Remaja Perokok; Studi Kualitatif di SMA Islam Lumajang. Jurnal Kesehatan Andalas. Vol. 2 (3), 128-135.

Mahmudah, Y., \& Lestari, Y. (2016). Faktor-Faktor yang Berhubungan dengan Perilaku Seksual Remaja di Kota Padang. Jurnal Kesehatan Andalas. Vol. 5 (2).

Muslimah, A. I., \& Wahdah, N. (2013). Hubungan Antara Attachment Dan Self Esteem Dengan Need for Achievement Pada Siswa Madrasah Aliyah Negeri 8 Cakung Jakarta Timur. Jurnal Soul. Vol. 6 (1).

Nia D. Dampak Seks Pranikah Pada Perempuan. (2014). Di unduh dari http://rona.metrotvnews.com/read/2 014/12/19/334005/dampak-sekspranikah-pada-\%20perempuan 
Nuandri, V. T., \& Widayat, I. W. (2014) Hubungan Antara Sikap terhadap Religiusitas dengan Sikap terhadap Kecenderungan Perilaku Seks Pranikah pada Remaja Akhir yang Sedang Berpacaran di Universitas Airlangga Surabaya. Jurnal Psikologi Kepribadian dan Sosial. Vol 3 (2).

Santrock, J. W. (2010). Adolescence, Thirteen Edition. New York: McGraw Hill.

Sari, C. P. (2009). Harga Diri Pada Remaja Putri Yang Telah Melakukan Hubungan Seks Pranikah. Jurnal Psikologi Universitas Gunadarma. Vol. 2 (2), 60-74.

Willig, C. (2008). Introducing Qualitative Research in Psychology, Second Edition. New York: McGraw Hill.

Yatim, D. I. (2015). Siapakah Remaja Itu? Jakarta: Badan Kependudukan dan Keluarga Berencana Nasional. 